\title{
HUBUNGAN LAMANYA HEMODIALISIS DENGAN TINGKAT KECEMASAN PADA PASIEN YANG MENJALANI HEMODIALISIS DI RUMAH SAKIT KOTA MEDAN
}

\author{
Harsudianto Silaen \\ Program Studi Ilmu Keperawatan \\ E-mail : silaenanto@gmail.com
}

\begin{abstract}
Hemodialysis is a renal replacement therapy performed 2-3 times a week with a duration of 4-5 hours, which aims to remove the remnants of protein metabolism and correct fluid and electrolyte disturbances. This study aims to determine the relationship duration of hemodialysis with anxiety level of hemodialysis patients in Teguh Hospital Murni. This research type is quantitative with cross sectional design. The samples used in this study amounted to 45 people and the sampling technique with purposive sampling is sampling by kebutulan researchers come to research and sebahagian sample was taken from the population. Data collection using questionnaire and data analysis using Chi Square test. From result of research got relationship of duration of hemodialysis with level of anxiety, with degree of meaning $(\alpha)$ 0,05 that is $X^{2}$ hitung: 12,01> $X^{2}$ table: 9,49, $p$ value: 0.00. It is desirable for nurses to provide education and more attention to hemodialysis patients undergoing hemodialysis less than 5 times in order for patients to feel comfortable and not anxious.
\end{abstract}

Keywords: Duration of Hemodialysis, Level of Anxiety.

\begin{abstract}
Abstrak
Hemodialisis merupakan terapi pengganti ginjal yang dilakukan 2-3 kali seminggu dengan lama waktu 4-5 jam, yang bertujuan untuk mengeluarkan sisa-sisa metabolisme protein dan mengoreksi gangguan keseimbangan cairan dan elektrolit. Penelitian ini bertujuan untuk mengetahui hubungan lamanya hemodialisis dengan tingkat kecemasan pasien hemodialisis di Rumah Sakit Murni Teguh. Jenis penelitian ini adalah kuantitatif dengan desain cross sectional. Sampel yang dipakai dalam penelitian ini berjumlah 45 orang dan teknik pengambilan sampel dengan purposive sampling yaitu pengambilan sampel secara kebutulan peneliti datang melakukan penelitian dan sebahagian sampel itu diambil dari jumlah populasi. Pengumpulan data menggunakan kuisioner dan analisa data menggunakan uji Chi Square. Dari hasil penelitian didapatkan hubungan lamanya hemodialisis dengan tingkat kecemasan, dengan derajat kemaknaan $(\alpha) 0,05$ yaitu $\mathrm{X}_{\text {hitung }}: 12,01>\mathrm{X}_{\text {tabel }}{ }: 9,49, p$ value $: 0.00$. Diharapkan kepada perawat untuk memberikan edukasi dan perhatian yang lebih kepada pasien hemodialisis yang sedang menjalani hemodialisis kurang dari 5 kali agar pasien merasa nyaman dan tidak cemas.
\end{abstract}

Kata kunci : Lamanya Hemodialisis, Tingkat Kecemasan

\section{PENDAHULUAN}

Penyakit ginjal kronis atau penyakit renal tahap akhir (ESRD) merupakan gangguan fungsi renal yang progresif dan irreversible dimana kemampuan tubuh gagal untuk mempertahankan metabolisme dan keseimbangan cairan dan elektrolit, menyebabkan uremia (retensi urea dan sampah nitrogen lain dalam darah) sehingga perlunya dilakukan hemodialisis. Hemodialisis merupakan suatu proses yang digunakan pada pasien dalam keadaan sakit akut dan memerlukan terapi dialisis jangka pendek (beberapa hari hingga beberapa minggu) atau pasien dengan penyakit ginjal stadium terminal (ESRD; endstage renal disease) yang membutuhkan terapi jangka panjang atau terapi permanen (Oktyantari., dkk, 2014).

Hemodialisis merupakan terapi pengganti ginjal yang dilakukan 2-3 kali 
seminggu dengan lama waktu 4-5 jam, yang bertujuan untuk mengeluarkan sisasisa metabolisme protein dan mengoreksi gangguan keseimbangan cairan dan elektrolit. Proses terapi hemodialisis yang membutuhkan waktu selama 5 jam, umumnya akan menimbulkan stres fisik pada pasien setelah hemodialisis. Pasien akan merasakan kelelahan, sakit kepala dan keluar keringat dingin akibat tekanan darah yang menurun, sehubungan dengan efek

hemodialisis. Ketergantungan pasien terhadap mesin hemodialisis seumur hidup, perubahan peran, kehilangan pekerjaan dan pendapatan merupakan stressor yang dapat menimbulkan depresi pada pasien hemodialisis dengan prevalensi 15\%-69\% (Septiwi, 2013).

Hemodialisis sebagai terapi utama dalam penanganan gangguan ginjal kronik, namun memiliki dampak bervariasi, diantaranya komplikasi intradialisis, efek hemodialisis kronik berupa kelelahan. Kelelahan memiliki prevalensi yang tinggi pada populasi pasien dialisis. Pada pasien yang menjalani hemodialisis dalam waktu lama, simptom kelelahan dialami $82 \%$ sampai $90 \%$ pasien (Sulistini., dkk, 2012).

Ketergantungan pada mesin dialisis seumur hidupnya, kondisi malnutrisi dan anemia yang terjadi pada pasien dialisis mengakibatkan terjadinya fatigue yang mempengaruhi fungsi kehidupan seharihari. Oleh karena itu, penatalaksanaan fatigue yang tepat dapat mencegah penurunan kualitas hidup pasien, diantaranya dengan pemberian massase yang dapat membantu menurunkan level fatigue pada pasien hemodialisis. Fatigue adalah perasaan subyektif yang tidak menyenangkan berupa kelelahan, kelemahan, dan penurunan energi dan merupakan keluhan utama pasien dengan dialisis (prevalensinya mencapai 60-97\%). Kondisi fatigue pada pasien hemodialisis dapat menyebabkan konsentrasi menurun, malaise, gangguan tidur, gangguan emosional, dan penurunan kemampuan pasien dalam melakukan aktivitas sehariharinya, sehingga pada akhirnya dapat menurunkan kualitas hidup pasien hemodialisis. Terdapat beberapa kondisi yang dapat mempengaruhi kondisi fatigue pada pasien hemodialisis menurut yaitu uremia, anemia, malnutrisi, depresi, dan kurangnya aktivitas fisik. Uremia pada pasien hemodialisis dapat menyebabkan pasien kehilangan nafsu makan, mual, muntah, kehilangan energi dan protein, dan penurunan produksi karnitin yang menyebabkan penurunan produksi energi untuk skeletal dan mengakibatkan fatigue (Septiwi, 2013).

Kualitas hidup pasien hemodialisa berfluktuasi, karena dipengaruhi oleh kesehatan fisik, psikologis, tingkat kemandirian, hubungan sosial, kepercayaan pribadi dan hubungan mereka dengan lingkungan. Pasien gagal ginjal yang menjalani hemodialisa seumur hidup membutuhkan dukungan perawat dan keluarga untuk meningkatkan kualitas hidupnya sehingga pasien yang menjalani HD akan dapat mempertahankan dan menstabilkan kemampuan fungsional, memenuhi kebutuhannya, menghilangkan gejala dan mengembalikan rasa nyaman dalam menjalani sisa hidupnya (Isroin, 2014).

Manajemen diri untuk pasien pada pengobatan hemodialisis sebagai proses "dari adaptasi perilaku sangat relevan, dengan premis yang mendasari adalah bahwa mengubah perilaku biasanya tidak terjadi sekaligus. Ketidakpatuhan dapat dilihat sebagai bentuk kurangnya manajemen diri, maka dari itu mendorong strategi berkelanjutan untuk manajemen diri mengurangi kecemasan merupakan tujuan penting bagi tim perawatan ginjal (Isroin, Istanti \& Soejono, 2014).

Kecemasan pada sakit fisik lainnya, seperti halnya kecemasan pada pasien penyakit ginjal kronik stadium terminal sering dianggap sebagai kondisi yang wajar terjadi. Penyakit ginjal kronik (PGK) stadium terminal menyebabkan pasien harus menjalani hemodialisis, 
oleh karena penyakit ginjal kronik (PGK) itu sendiri dapat mengakibatkan kecemasan maupun depresi pada pasien bertambah, sehingga sangat dibutuhkan dukungan sosial terhadap para penderita. Adanya kompleksitas masalah yang timbul selama hemodialisis akan berdampak terjadinya kecemasan pada pasien. Gangguan psikiatrik yang sering ditemukan pada pasien dengan terapi hemodialisis adalah depresi, kecemasan, hubungan dalam perkawinan, serta ketidakkepatuhan dalam diet dan obatobatan. Keterbatasan pola atau kebiasaan hidup dan ancaman kematian. Oleh karena itu banyak pasien dan keluarganya memerlukan dukungan secara emosional untuk mengahadapi kecemasan tentang penyakitnya (Agustin., dkk, 2013).

Angka kejadian Chronic Kidney Disease (CKD) meningkat dari tahun ke tahun. Jumlah CKD di dunia tahun 2009 di Amerika Serikat rata-rata prevalensinya $10-13 \%$ atau sekitar 25 juta orang yang terkena Penyakit Ginjal Kronik. Sedangkan di Indonesia tahun 2009 prevalensinya $12,5 \%$ atau 18 juta orang dewasa yang terkena penyakit ginjal kronik (Hidayati., dkk, 2014).

Kejadian penyakit gagal ginjal di Indonesia semakin meningkat. Penyakit ini digambarkan seperti fenomena gunung es, dimana hanya sekitar $0,1 \%$ kasus yang terdeteksi, dan 11-16\% yang tidak terdeteksi. Menurut data statistik yang dihimpun oleh Perhimpunan Nefrologi Indonesia (PERNEFRI), jumlah pasien gagal ginjal di Indonesia mencapai 70.000 orang dan hanya sekitar 13.000 pasien yang melakukan cuci darah atau hemodialisis (Septiwi, 2013).

Berdasarkan hasil survei pendahuluan yang dilakukan oleh peneliti menemukan jumlah pasien hemodialisa sebanyak 62 orang dan peneliti melakukan wawancara singkat menemukan bahwa pasien yang sedang menjalani hemodialisa yang pertama kali sampai dengan hemodialisa kelima bahwa pasien mengatakan kebanyakan merasakan cemas dan sangat takut terhadap proses cuci darah. Pasien yang menjalani hemodialisis akan membutuhkan waktu yang lama ketika pasien tersebut memiliki berat badan yang abnornal dari biasanya sehingga perlu dilakukan cuci darah yang membutuhkan waktu yang lama.

\section{METODE PENELITIAN}

Jenis penelitian ini adalah kuantitatif dengan design cross sectional. Teknik pengambilan sampel menggunakan metode non random sampling dengan accidental sampling. Penelitian ini telah dilakukan di Murni Teguh Memorial Hospital pada bulan Januari-Maret 2018. Sampel yang dipakai dalam penelitian ini berjumlah 45 orang yang menjalani hemodialisa $\leq 1$ tahun dan mengalami kecemasan.

Teknik pengambilan sampel dengan purposive sampling yaitu pengambilan sampel secara kebutulan peneliti datang melakukan penelitian dan sebahagian sampel itu diambil dari jumlah populasi. Sampel ditentukan berdasarkan kriteria inklusi adalah yang menjalani hemodialisa $\leq 1$ tahun dan kooperatif terhadap pemberian data tentang kecemasan sebanyak 45 orang dan analisa data menggunakan uji Chi Square dengan melihat nilai $p$ value < 0,05 .

Terdapat 3 tahapan dalam proses pelaksanaan, yaitu 1) Tahap pertama : peneliti terlebih dahulu memberikan format data demografi untuk dapat diisi oleh responden, 2) Tahap kedua : peneliti mengajukan kuisioner dan mengukur tingkat kecemasan, 3) Tahap ketiga : peneliti melakukan analisis data univariat dan bivariat dengan menghubungkan antara variabel independent dan variabel dependent dengan memakai distribusi frekuensi pada sistem komputerisasi.

\section{HASIL PENELITIAN \\ Analisa Univariat}

Karakteristik Responden ( $\mathrm{N}=\mathbf{4 5}$ )

Berdasarkan hasil penelitian yang diperoleh, umur pasien hemodialisis, 3545 tahun yaitu sebanyak 12 orang 
(26,7\%), umur 46-55 tahun yaitu sebanyak 22 orang $(48,9 \%)$ dan umur $>55$ tahun yaitu sebanyak 11 orang (24,4\%). Pekerjaan pasien hemodialisis, PNS yaitu sebanyak 13 orang $(28,9 \%)$, pekerjaan wirausaha yaitu sebanyak 19 orang $(42,2 \%)$ dan pekerjaan IRT yaitu sebanyak 6 orang $(13,3 \%)$ dan pekerjaan lain-lainnya sebanyak 7 orang $(15,6 \%)$. Pendidikan pasien hemodialisis, SD yaitu sebanyak 1 orang (2,2\%), pendidikan SMP yaitu sebanyak 13 orang $(28,9 \%)$ dan pendidikan SMA yaitu sebanyak 25 orang $(57,8 \%)$ dan pendidikan Perguruan Tinggi sebanyak 5 orang $(11,1 \%)$.

\begin{tabular}{|c|c|c|c|c|}
\hline \multicolumn{5}{|c|}{$\begin{array}{l}\text { Distribusi Frekuensi Berdasarkan } \\
\text { Lamanya Hemodialisis } \\
\text { Tingkat Kecemasan pada Pasien } \\
\text { Hemodialisis di Rumah Sakit Murn } \\
\text { Teguh }(n=45) \text {. }\end{array}$} \\
\hline No & $\begin{array}{c}\text { Lamanya } \\
\text { HD }\end{array}$ & $\begin{array}{c}\text { Jumlah } \\
\text { (n) }\end{array}$ & & $\begin{array}{l}\text { rsentas } \\
\text { e }(\%)\end{array}$ \\
\hline 1 & 4-5 Jam & 30 & & 66,7 \\
\hline 2 & - 5 Jam & 15 & & 33,3 \\
\hline & Total & 45 & & 100 \\
\hline
\end{tabular}

Berdasarkan tabel di atas dapat dilihat bahwa, lamanya hemodialisis, 45 jam yaitu sebanyak 30 orang $(66,7 \%)$, dan $>5$ jam sebanyak 15 orang $(33,3 \%)$.

\begin{tabular}{|c|c|c|c|}
\hline \multicolumn{2}{|c|}{$\begin{array}{lr}\text { Distribusi } & \text { Fr } \\
\text { Tingkat } & K \\
\text { Hemodialisis } & \text { d } \\
\text { Teguh }(n=45) .\end{array}$} & \multicolumn{2}{|c|}{ 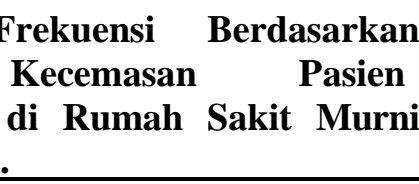 } \\
\hline No & $\begin{array}{c}\text { Tingkat } \\
\text { Kecemasa } \\
\text { n }\end{array}$ & $\begin{array}{c}\text { Jumlah } \\
\text { (n) }\end{array}$ & $\begin{array}{c}\text { Persentas } \\
\text { e (\%) }\end{array}$ \\
\hline 1 & $\begin{array}{l}\text { Tidak } \\
\text { cemas }\end{array}$ & 30 & 66,7 \\
\hline 2 & $\begin{array}{l}\text { Cemas } \\
\text { ringan }\end{array}$ & 7 & 15,6 \\
\hline 3 & $\begin{array}{l}\text { Cemas } \\
\text { Sedang }\end{array}$ & 5 & 11,1 \\
\hline 4 & $\begin{array}{l}\text { Cemas } \\
\text { berat }\end{array}$ & 2 & 4,4 \\
\hline 5 & $\begin{array}{l}\text { Cemas } \\
\text { berat } \\
\text { sekali }\end{array}$ & 1 & 2,2 \\
\hline & Total & 45 & 100 \\
\hline
\end{tabular}

Berdasarkan tabel di atas dapat dilihat bahwa, tingkat kecemasan pasien hemodialisis, tidak cemas yaitu sebanyak 30 orang $(66,7 \%)$, cemas ringan yaitu sebanyak 7 orang $(15,6 \%)$ dan cemas sedang yaitu sebanyak 5 orang $(11,1 \%)$, cemas berat yaitu sebanyak 2 orang $(4,4 \%)$ dan cemas berat sekali yaitu sebanyak 1 orang $(2,2 \%)$.

\section{Analisa Bivariat}

Hubungan Lamanya Hemodialisis dengan Tingkat Kecemasan pada Pasien Hemodialisis di Rumah Sakit Murni Teguh $(\mathbf{N}=45)$

\begin{tabular}{ccc}
\multicolumn{2}{c}{ Murni Teguh $(\mathbf{N}=\mathbf{4 5})$} \\
\hline $\mathrm{X}^{2}$ Hitung & $\mathrm{X}^{2}$ Tabel & $p$ value \\
\hline 12,01 & $\underline{9,49}$ & $\underline{0,00}$ \\
\hline
\end{tabular}

Berdasarkan tabel diatas diperoleh bahwa nilai $\mathrm{p}$ value 0,00 . Nilai $\alpha<0,05$ maka dapat disimpulkan bahwa terdapat hubungan yang signifikan antara lamanya hemodialisis dengan tingkat pasien hemodialisis.

\section{PEMBAHASAN}

Dari hasil penelitian yang dilakukan peneliti dinyatakan bahwa didapatkan hubungan yang signifikan antara lamanya hemodialisis dengan tingkat kecemasan pada pasien hemodialisis. Pasien gagal ginjal yang menjalani hemodialisa seumur hidup membutuhkan dukungan perawat dan keluarga untuk meningkatkan kualitas hidupnya sehingga pasien yang menjalani HD akan dapat mempertahankan dan menstabilkan kemampuan fungsional, memenuhi kebutuhannya, menghilangkan gejala dan mengembalikan rasa nyaman dalam menjalani sisa hidupnya (Isroin, 2014).

Penyakit ginjal kronis atau penyakit renal tahap akhir (ESRD) merupakan gangguan fungsi renal yang progresif dan irreversible dimana kemampuan tubuh gagal untuk mempertahankan metabolisme dan keseimbangan cairan dan elektrolit, menyebabkan uremia (retensi urea dan sampah nitrogen lain dalam darah) sehingga perlunya dilakukan hemodialisis. Hemodialisis merupakan suatu proses yang digunakan 
pada pasien dalam keadaan sakit akut dan memerlukan terapi dialisis jangka pendek (beberapa hari hingga beberapa minggu) atau pasien dengan penyakit ginjal stadium terminal (ESRD; endstage renal disease) yang membutuhkan terapi jangka panjang atau terapi permanen (Oktyantari., dkk, 2014).

Hemodialisis sebagai terapi utama dalam penanganan gangguan ginjal kronik, namun memiliki dampak bervariasi, diantaranya komplikasi intradialisis, efek hemodialisis kronik berupa kelelahan. Kelelahan memiliki prevalensi yang tinggi pada populasi pasien dialisis. Pada pasien yang menjalani hemodialisis dalam waktu lama, simptom kelelahan dialami $82 \%$ sampai $90 \%$ pasien (Sulistini., dkk, 2012).

Kualitas hidup pasien hemodialisa berfluktuasi, karena dipengaruhi oleh kesehatan fisik, psikologis, tingkat kemandirian, hubungan sosial,kepercayaan pribadi dan hubungan mereka dengan lingkungan. Pasien gagal ginjal yang menjalani hemodialisa seumur hidup membutuhkan dukungan perawat dan keluarga untuk meningkatkan kualitas hidupnya sehingga pasien yang menjalani HD akan dapat mempertahankan dan menstabilkan kemampuan fungsional, memenuhi kebutuhannya, menghilangkan gejala dan mengembalikan rasa nyaman dalam menjalani sisa hidupnya (Isroin, 2014)

Kecemasan pada sakit fisik lainnya, seperti halnya kecemasan pada pasien penyakit ginjal kronik stadium terminal sering dianggap sebagai kondisi yang wajar terjadi. Penyakit ginjal kronik (PGK) stadium terminal menyebabkan pasien harus menjalani hemodialisis, oleh karena penyakit ginjal kronik (PGK) itu sendiri dapat mengakibatkan kecemasan maupun depresi pada pasien bertambah, sehingga sangat dibutuhkan dukungan sosial terhadap para penderita. Adanya kompleksitas masalah yang timbul selama hemodialisis akan berdampak terjadinya kecemasan pada pasien. Gangguan psikiatrik yang sering ditemukan pada pasien dengan terapi hemodialisis adalah depresi, kecemasan, hubungan dalam perkawinan, serta ketidakkepatuhan dalam diet dan obatobatan. Keterbatasan pola atau kebiasaan hidup dan ancaman kematian. Oleh karena itu banyak pasien dan keluarganya memerlukan dukungan secara emosional untuk mengahadapi kecemasan tentang penyakitnya (Agustin., dkk, 2013).

Hemodialisis merupakan terapi pengganti ginjal yang dilakukan 2-3 kali seminggu dengan lama waktu 4-5 jam, yang bertujuan untuk mengeluarkan sisasisa metabolisme protein dan mengoreksi gangguan keseimbangan cairan dan elektrolit. Proses terapi hemodialisis yang membutuhkan waktu selama 5 jam, umumnya akan menimbulkan stres fisik pada pasien setelah hemodialisis. Pasien akan merasakan kelelahan, sakit kepala dan keluar keringat dingin akibat tekanan darah yang menurun, sehubungan dengan efek

hemodialisis. Ketergantungan pasien terhadap mesin hemodialisis seumur hidup, perubahan peran, kehilangan pekerjaan dan pendapatan merupakan stressor yang dapat menimbulkan depresi pada pasien hemodialisis dengan prevalensi 15\%-69\% (Septiwi, 2013).

Berdasarkan hasil penelitian yang diperoleh dengan lamanya hemodialisis 4-5 jam mengalami tidak cemas sebanyak 30 orang. Hal ini disebabkan pasien yang menjalani hemodialisis tidak mudah menyerah dan selalu mempunyai persepsi hidup sehat walaupun melakukan hemodialisis. Hemodialisis yang telah dilakukan 30 orang tersebut merupakan hemodialisis yang belum lama dijalani, akan tetapi pasien tetap mempunyai semangat untuk melakukan hemodialisis.

Berdasarkan hasil penelitian yang diperoleh dengan lamanya hemodialisis $>5$ jam dengan cemas berat sekali, cemas berat, cemas sedang dan cemas ringan. Hasil penelitian ini diperoleh dari responden yang memiliki persepsi dan pengetahuan yang rendah tentang 
hemodialisis sehingga pasien memiliki pemikiran yang negatif dan membuat pikiran tidak stabil. Pikiran yang tidak stabil dapat menganggu jalannya proses hemodialisis, diharapkan proses hemodialisis tidak menjadi suatu penghambat untuk menjadi lebih baik.

Menurut asumsi peneliti, lamanya hemodialisis 4-5 jam dengan tingkat kecemasan ringan dikarenakan pasien hemodialisis yang memiliki pengetahuan dan pola pemikiran terhadap proses hemodialisis sehingga pasien dapat meningkatkan kualitas hidup pasien.

Menurut asumsi peneliti, bahwa lamanya hemodialisis $>5$ jam dengan tingkat kecemasan yang berat sekali, berat dan sedang merupakan pasien hemodialisis yang tidak bisa mengontrol pola pikir dan rasa kekhawatiran untuk bertahan hidup sehingga pasien dapat menjadi merasa hemodialisis merupakan hal yang ditakuti. Dalam hal ini tingkat kecemasan dapat dicegah dengan berbagai cara yaitu memberikan dukungan sosial kepada pasien, dukungan sosial yang dimaksud adalah dukungan keluarga dimana keluarga memberikan dukungan yang penuh agar pasien dapat termotivasi dan mempunyai semangat untuk menjalani hemodialisa. Dukungan keluarga sangat dibutuhkan pasien dalam menjalani pengobatan termasuk menjalani hemodialisa yang butuh waktu yang lama dan kesabaran.

Hasil penelitian Septiwi dapat mendukung penelitian ini, bahwa proses terapi hemodialisis yang membutuhkan waktu selama 5 jam, umumnya akan menimbulkan stres fisik pada pasien setelah hemodialisis. Pasien akan merasakan kelelahan, sakit kepala dan keluar keringat dingin akibat tekanan darah yang menurun, sehubungan dengan efek hemodialisis. Ketergantungan pasien terhadap mesin hemodialisis seumur hidup, perubahan peran, kehilangan pekerjaan dan pendapatan merupakan stressor yang dapat menimbulkan depresi pada pasien hemodialisis dengan prevalensi $15 \%$ 69\% (Septiwi, 2013).

\section{KESIMPULAN}

Kesimpulan hasil penelitian ini adalah

a. Terdapat hubungan yang signifikan antara lamanya hemodialisis dengan tingkat kecemasan.

b. Mayoritas umur pasien hemodialisis, umur 46-55 tahun yaitu sebanyak 22 orang $(48,9 \%)$, mayoritas pekerjaan pasien hemodialisis pekerjaan wirausaha yaitu sebanyak 19 orang $(42,2 \%)$, mayoritas pendidikan pasien hemodialisis pendidikan SMA yaitu sebanyak 25 orang $(57,8 \%)$.

\section{SARAN}

a. Rumah Sakit

Diharapkan kepada perawat untuk memberikan edukasi dan perhatian yang lebih kepada pasien hemodialisis yang sedang menjalani hemodialisis kurang dari 5 kali agar pasien merasa nyaman dan tidak cemas.

b. Bagi Pendidikan keperawatan

Dari hasil penelitian ini diharapkan dapat menjadi informasi tambahan dan masukan dalam pengembangan pendidikan keperawatan terhadap mengatasi kecemasan dengan intervensi keperawatan.

c. Bagi Peneliti Selanjutnya

Diharapkan bagi peneliti selanjutnya untuk menambah variabel lain untuk melihat faktor yang terkait terhadap timbulnya kecemasan dan solusi untuk menangani kecemasan.

\section{REFERENSI}

Agustin, W, dkk, (2013). Tingkat kecemasan yang dilakukan tindakan hemodialisa di Ruang Hemodialisa RSUD DR Seohadi Prijonegoro Sregan. Jurnal Ilmu Kesehatan Vol 3. No 2. 2013.

Hidayati, S., dkk, (2012). Efektifitas Konseling Analisis Transaksional Tentang Diet Cairan Terhadap Penurunan Interdialytic Weight Gain (IDWG) Pasien Gagal Ginjal Kronis Yang Menjalani Hemodialisa Di Rumah Sakit 
Umum Daerah Kardinah. Jurnal Ilmu Kesehatan Vol 3. No 2. 2012.

Isroin, L., Istanti, Y.P., \& Soejono, S.K, (2014). Manajemen Cairan pada Pasien Hemodialisis untuk Meningkatkan Kualitas Hidup di RSUD Dr. Harjono Ponorogo. Jurnal Keperawatan Vol 2 No 1 Tahun 2014.

Oktyantari, P, dkk, (2014). Efektivitas Terapi Slow Stroke Back Massage terhadap Penurunan Tingkat Fatigue pada Pasien yang menjalani Hemodialisa di RSUD dr. Moewardi Surakarta. ISBN : 978-602-97846-3-3

Septiwi, C, (2013). Pengaruh Breathing Exercise terhadap Level Fatique Pasien Hemodialisis di RSPAD Gatot Subroto Jakarta. Jurnal keperawatan (The Soedirman Journal of Nursing, Volume 8, No. 1 Maret 2013).

Sulistini, R., Yetti, K. \& Hariyati, T S, (2012). Faktor-faktor yang memperngaruhi Fatique pada Pasien yanga Menjalani Hemodialisa. Jurnal Keperawatan Indonesia, Volume 15 No 2, Hal 75-82 